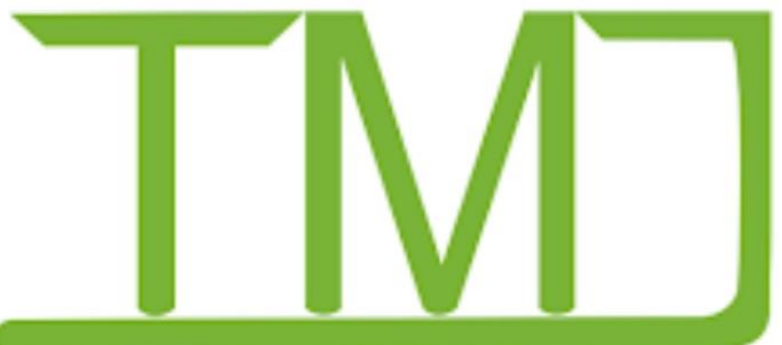

Technomedia Journal

iLearning Journal Center (iJC)

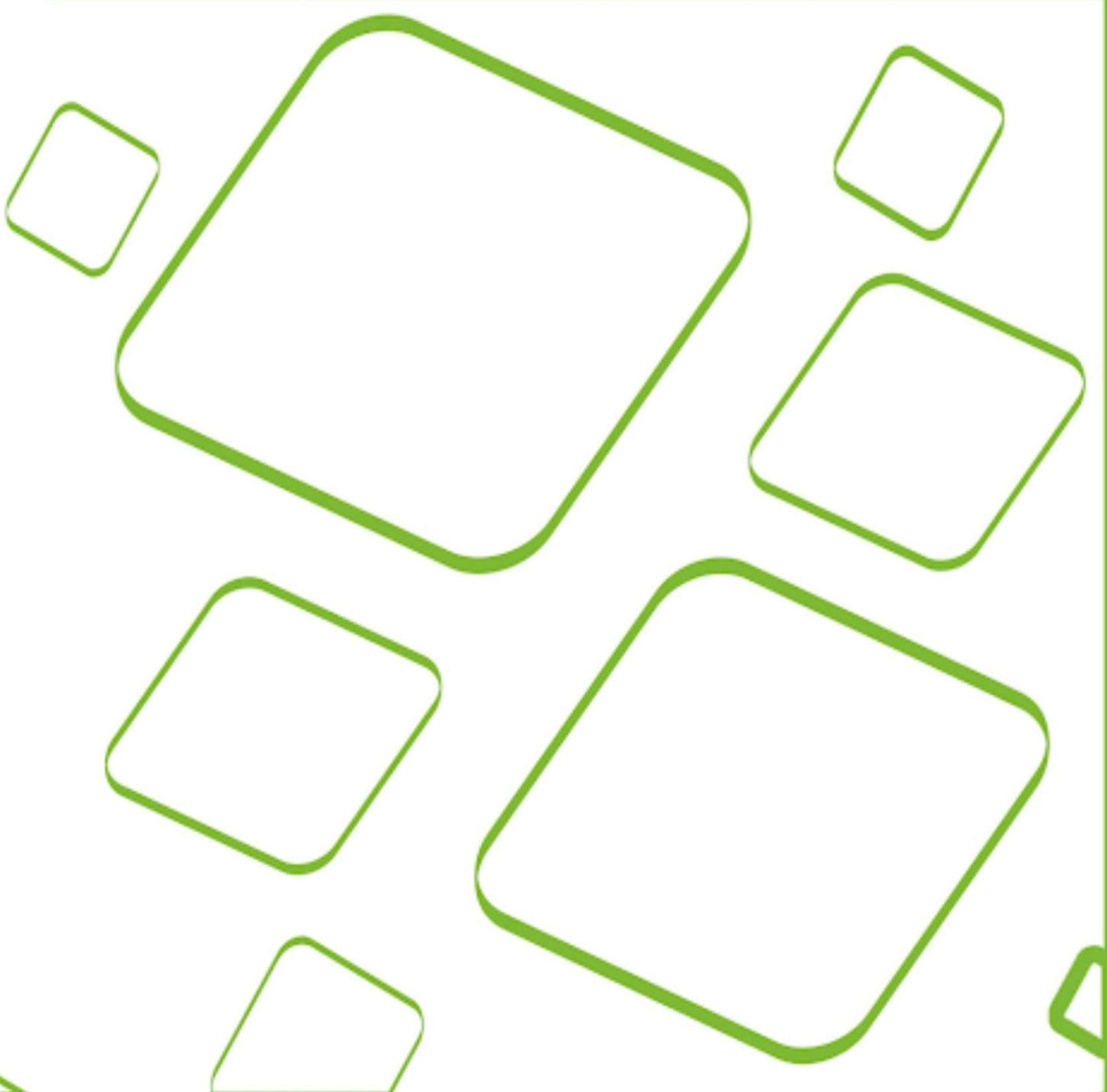


Technomedia Journal adalah jurnal elektronik ilmiah yang diterbitkan oleh iJC (iLearning Journal Center). Technomedia Journal terbit tiga kali dalam satu tahun Februari, Juni, dan Oktober yang berisi artikel hasil penelitian dalam bidang Sistem Informasi dan Teknologi Informatika.

\section{Ketua Redaksi :}

Ir. Untung Rahardja.,M.T.I

Sekretaris Redaksi :

Indri Handayani, S.Kom., M.T.I

\section{Mitra Bestari :}

Prof. Ir. Joko Lianto Buliali, M.Sc.,Ph.D

Prof. Dr.rer.nat. Achmad Benny Mutiara, SSi, SKom

Prof. Dr. Moedjiono. MSc

Dr. Winarno

Dr. Harco Lesly

Panca Oktavia Hadi Putra, Bsc., M.Sc.,

Henderi, M.Kom

Dr. Ir. I. Joko Dewanto, MM

Dr. Ir. Sudatyono, S.Pd., M.Pd

\section{Editor/ Layout : \\ Maulana Sani \\ Yuli Widiastuti}

\section{Bendahara:}

Eka Purnama Harahap, S.Kom

\section{Alamat Redaksi :}

Jl. Jendral Sudirman No 40, Cikokol - Tangerang Tel / fax : (021)5529692

Email: ijc@ raharjagroups.info atau ijc@ raharja.info 


\section{Dewan Redaksi}

Puji dan syukur kehadirat Allah SWT atas karunia dan lindunganNya sehingga TMJ terbitan Vulume 1 Nomor 1 Edisi Oktober 2016 dapat diterbitkan tepat waktu.

Penerbitan jurnal ini dimaksudkan sebagai media informasi ilmiah dibidang ilmu komputer yang diharapkan dapat membantu para dosen dan mahasiswa dalam menginformasikan hasil penelitian dan kajian ilmiah lainnya kepada berbagai komunitas ilmiah diseluruh Indonesia.

Penerbitan jurnal Volume 1 Nomor 1 Edisi Oktober 2016 berisikan 10 artikel yang mencakup bidang Ilmu Komputer, Teknologi Informasi, Sistem Informasi, walaupun tidak seluruhnya merupakan hasil penelitian diharapkan dapat bermanfaat bagi pembacanya. Puji syukur kehadirat Allah SWT karena 10 artikel adalah dari STMIK dan AMIK Raharja.

Jurnal ini diterbitkan dengan memuat artikel Fitur Form Emailer Dalam Memaksimalkan Penggunaan Rinfo Form Pada Perguruan Tinggi, Implementasi Fgr (First Generation Resources) Dengan Menggunakan Mailchimp Sebagai Sarana Informasi Di Perguruan Tinggi, Optimalisasi Penerapan Rooster Berbasis Osticket Untuk Meningkatkan Mutu Pelayanan, Penerapan Rinfosheet Sebagai Media Penunjang Pembuatan Laporan Untuk Mahasiswa, Penerapan Rinfosheet Sebagai Media Penunjang Pembuatan Laporan Untuk Mahasiswa, Optimalisasi Viewboard Rhjfox Berbasis Bootstrap Sebagai Sistem Penunjang Keputusan, Penerapan Viewboard Go+ Berbasis Yii Sebagai Media Monitoring Pembayaran Mahasiswa, Pemanfaatan Rinfo Form Sebagai Media Pembuatan Kuesioner Dalam Proses Pengumpulan Data Pada Perguruan Tinggi, Pemanfaatan Google Scholar Dan Citation Dalam Memenuhi Kebutuhan Pembuatan Skripsi Mahasiswa Pada Perguruan Tinggi, Penerapan Mata Uang Armo (Airzone-Mall Money) Pada Marketplace Airzone-Mall Sebagai Inovasi Pembelajaran Internet Dan E-Commerce, Media Audio Visual Menggunakan Videoscribe Sebagai Penyajian Informasi Pembelajaran Pada Kelas Sistem Operasi.

Tidak lupa pula pada kesempatan ini kami mengundang para pembaca untuk mengirimkan naskah hasil penelitian kepada kami. Dan tidak lupa pula kami mengucapkan banyak terimakasih kepada semua pihak yang telah membantu penerbitan jurnal ini.

Tangerang, 31 Oktober 2016

Redaksi 


\section{Daftar Isi}

1. FITUR FORM EMAILER DALAM MEMAKSIMALKAN PENGGUNAAN RINFO FORM PADA PERGURUAN TINGGI.................................................... Indri Handayani, Qurotul Aini, Reza Alfiansah

2. IMPLEMENTASI FGR (FIRST GENERATION RESOURCES) DENGAN MENGGUNAKAN MAILCHIMP SEBAGAI SARANA INFORMASI DI PERGURUAN TINGGI. Qurotul Aini, Indri Handayani, Nuril Huda

3. OPTIMALISASI PENERAPAN ROOSTER BERBASIS OSTICKET UNTUK MENINGKATKAN MUTU PELAYANAN. Untung Rahardja, Khanna Tiara, Ria Utami

4. PENERAPAN RINFOSHEET SEBAGAI MEDIA PENUNJANG PEMBUATAN LAPORAN UNTUK MAHASISWA ... Khanna Tiara, Erlita Rasdiana, Nursam Somantri

5. OPTIMALISASI VIEWBOARD RHJFOX BERBASIS BOOTSTRAP SEBAGAI SISTEM PENUNJANG KEPUTUSAN...... Untung Rahardja, Khanna Tiara, Maya Ima Erviani

6. PENERAPAN VIEWBOARD GO+ BERBASIS YII SEBAGAI MEDIA MONITORING PEMBAYARAN MAHASISWA .............. $\quad$ 65-77 Khanna Tiara, Tuti Nurhaeni, Ika amalia

7. PEMANFAATAN RINFO FORM SEBAGAI MEDIA PEMBUATAN KUESIONER DALAM PROSES PENGUMPULAN DATA PADA PERGURUAN TINGGI. Erlita Rasdiana, Fadil Nur Muhamad, Ridwan Kurniaji

8. PEMANFAATAN GOOGLE SCHOLAR DAN CITATION DALAM MEMENUHI KEBUTUHAN PEMBUATAN SKRIPSI MAHASISWA PADA PERGURUAN TINGGI....................... Untung Rahardja, Khanna Tiara, Iis Ariska Rosalinda

9. PENERAPAN MATA UANG ARMO (AIRZONE-MALL MONEY) PADA MARKETPLACE AIRZONE-MALL SEBAGAI INOVASI PEMBELAJARAN INTERNET DAN E-COMMERCE. Qurotul Aini, Untung Rahardja, Dita Lintang Nurani

10. MEDIA AUDIO VISUAL MENGGUNAKAN VIDEOSCRIBE SEBAGAI PENYAJIAN INFORMASI PEMBELAJARAN PADA KELAS SISTEM OPERASI. 


\title{
Implementasi Fgr (First Generation Resources) Dengan Menggunakan Mailchimp Sebagai Sarana Informasi Di Perguruan Tinggi
}

\author{
Qurotul Aini ${ }^{1}$ \\ Indri Handayani ${ }^{2}$ \\ Nuril Huda ${ }^{3}$ \\ Jl. Jend. Sudirman No. 40, Modern Cikokol, Tangerang ${ }^{1,2,3}$ \\ E-mail : aini@raharja.info $^{1}$, indri@raharja.info $^{2}$, nuril@raharja.info $^{3}$
}

\begin{abstract}
ABSTRAKSI
Proses tool digital marketing itu sangat penting dalam penyebaran informasi yang sangat berkualitas dan menarik. Di beberapa Perguruan Tinggi sudah menerapkan tool digital marketing. namun proses yang sebelumnya yang berjalan masih dalam ruang lingkup yang kecil. sedangkan yang membutuhkan tool digital marketing ini sangat banyak untuk menyebarkan informasi. dalam penelitian ini terdapat 3 masalah perihal konsep tool digital marketing. jalan keluar masalah ini adalah yaitu dengan menerapkan MailChimp. tool digital marketing ini diharapkan bisa sangat berguna bagi para dosen ataupun mahasiswa/i dalam penyebaran informasi secara modern. Sangat diharapkan penyebaran informasi FGR (First Generation Resources) dengan menggunkan tool digital marketing yaitu MailChimp dapat berguna di Perguruan Tinggi.
\end{abstract}

Kata kunci: plagiarisme, FGR, MailChimp

\begin{abstract}
The process of digital marketing tool that is very important in the dissemination of information that is very high quality and attractive. In some universities are already implementing digital marketing tool. but the process before running still in small scope. while requiring digital marketing tool is very much to spread information. in this study there are three problems concerning the concept of digital marketing tool. way out of this problem is by implementing MailChimp. This digital marketing tool is expected to be very useful for professors or students in modern information dissemination. It is desirable dissemination of information FGR (First Generation Resources) by using digital marketing tool that can be useful in MailChimp College.
\end{abstract}

Keywords: plagiarism, FGR, MailChimp

\section{PENDAHULUAN}

Pada era globalisasi yang sudah sangat maju ini apapun bisa didapatkan dengan dengan adanya internet semua bisa terwujudkan. Kemajuan teknologi saat ini memang sudah tidak diragukan lagi karna semua sudah sangat dipermudah, dengan semua kemajuan teknologi ini tidak sedikit dari orang-orang yang banyak menyalahgunakan, Kejahatan di dunia maya yang sudah beredar luas dan sering dilakukan di dunia internet. salah satunya yaitu plagiarisme pada suatu karangan, karya ilmiah, hal tersebut sangat merugikan bagi pengarang.

Kutipan dari Rektor UNS ( Universitas Sebelas Maret ), Prof. Dr. Ravik Karsidi, MS dosen dan mahasiswa untuk mengunggah karya mereka ke dalam sistem, yang selanjutnya akan dipindai dan diperiksa orisinalitasnya dibandingkan dengan karya-karya lain yang telah 
dipublikasikan. Sebelum ujian, baik thesis, disertasi dan karya ilmiah apapun harus diunggah dulu untuk similarity test. Nanti ketahuan apakah karya ini plagiat ini atau tidak.

Tidak sedikit orang yang melakukan plagiarisme pada karangan atau karya ilmiah entah tidak mengetahui atau bahkan memang sengaja dilakukan padahal hal tersebut suatu kejahatan di dunia maya (Cyber Crime). copy paste pada karangan dan karya ilmiah memang terlihat sudah biasa dikalangan pengguna internet tetapi dampak dari hal tersebut cukup serius, karna sudah ada pidana hukum jika memplagiat, Tindak plagiarisme sudah meluas di dunia maya oleh karna itu sudah banyak sekali jasa scan plagiarisme yang disediakan di internet dari yang gratis hingga berbayar sesuai kebutuhan, Dengan banyaknya jasa scan plagiarisme ini diharapkan dapat mengecilnya tindak plagiarism di dunia maya.

Untuk dapat memperkenalkan lebih luas lagi jasa scan plagiarisme kekhalayak maka dibutuhkan suatu startegi penyebaran informasi yang berbasis media elektronik yang modern dan menarik bagi orang yang akan membacanya, yang terkenal saat ini media penyebaran informasi adalah tool digital marketing sudah banyak di internet. Tool digital marketing ini diperuntunkan untuk para enterpreneur dalam menyebarkan informasi atau product yang ditawarkan dan tool digital marketing ini sangat cocok dalam memperkenalkan jasa scan plagiarisme kepada banyak orang.

\section{LANDASAN TEORI}

\section{Definisi MailChimp}

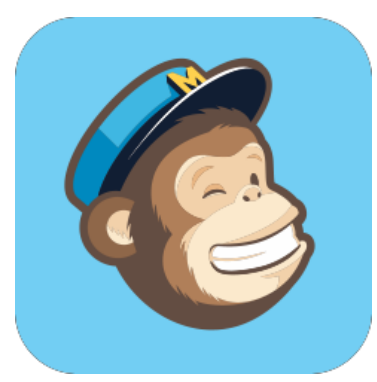

Menurut Yusup :2014) MailChimp adalah penyedia layanan email pemasaran dan merupakan suatu aplikasi berbasis web.Sedangkan menurut situs resminya dijabarka sebagai berikut: email simpanse telah ada sejak tahun 2001, kami didemonstrasikan sebagai proyek sampingan yang didanai oleh berbagai pekerjaan web-diharapkan pengembangan. sekarang mengirim lebih dari 600 juta email sehari. kita suka melihat bisnis mulai dari yang kecil, mendanai diri dengan proyek membayar, dan membangun sebuah API yang kuat, sehingga cara dijalankan MailChimp. kita menciptakan prosucts dan freatures yang memberdayakan pelanggan kami untuk tumbuh

\section{Definisi FGR (First Generation Resources)}

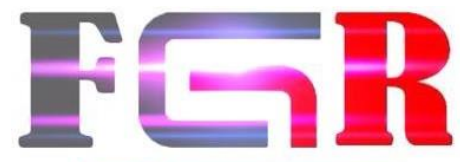

First Generation Resaurces 
FGR Services ( First Generation Resources ) adalah suatu penjualan jasa Scan Plagiarisme yang dimana jasa ini bertujuan untuk pencegahan plagiat yang sudah termasuk kedalam kejahatan di dunia maya dan dengan adanya FGR ingin menghentikan penjiplakan karya ilmiah/karangan orang lain yang sudah sangat tinggi. Product yang ditawarkan oleh FGR Services cukup unik ada 4 Package yang ditawarkan yaitu: Diamond Green, Silver, Gold, Platinum.

\section{PERMASALAHAN}

Penyebaran informasi yang sedang berjalan saat ini terlihat masih manual, dengan menggunakan kertas paper, banner, formulir, spanduk, billboard dan sebagainya. Sehingga penyebaran informasi dengan menggunakan tool ini belum berjalan dengan efektif dan tidak terlihat secara signifikan. Dengan demikian mahasiswa tidak mendapatkan informasi yang up to date seputar kampus.

Divisi yang menyebarkan informasi seputar kampus yaitu pihak devisi marketing yang dimana penyebaran kepada calon mahasiswa masih menggunakan kertas dan formulir, hal tersebut kurang efektif mengingat saat ini teknologi sudah berbasis IT dan penyebaran informasi telah menggunakan media elektronik. Saat ini Perguruan Tinggi sudah menerapkan penyebaran informasi dengan menggunakan media elektronik, dengan begitu penggunaa kertas dapat di minimalisir. Oleh karena itu dibutuhkan suatu tool marketing yang dapat menyebarkan informasi menggunakan elektronik salah satu tool marketing yang sering digunakan yaitu MailChimp.

Setelah analisa yang sudah dilakukan oleh penulis di Perguruan Tinggi, tool digital marketing MailChimp bahwa tool digital marketing ini belum berjalan secara efektif oleh sebab itu berdasarkan analisa dari segi kekurangan yang ada serta untuk memenuhi kebutuhan saat ini terdapat 3 (tiga) permasalahan, diantaranya:

1. Tool marketing belum terimplementasi secara baik di Perguruan Tinggi.

2. Dalam penyebaran informasi di Perguruan Tinggi masih manual.

3. Masih minim penggunaan tool marketing di Perguruan Tinggi.

\section{LITERATURE REVIEW}

1. Penelitian ini telah dilakukan oleh I Wayan Putra Yasa (2010) yang berjudul Kejahatan Didunia Maya (Cyber Crime)." Syarat sah jual beli online, sama dengan jual-beli pada umumnya sesuai dengan ketentuan didalam KUHPerdata, yakni harus memenuhi semua unsur yang terkandung dalam Pasal 1320 KUHPerdata, mengenai syaratsyarat sahnya perjanjian, dan telah memenuhi Pasal 1457 KUHPerdata mengenai perjanjian jual beli.

2. Penelitian ini telah dilakukan oleh Wikipedia (2015) yang berjudul "Plagiarisme" Plagiarisme atau sering disebut plagiat adalah penjiplakan atau pengambilan karangan, pendapat, dan sebagainya dari orang lain dan menjadikannya seolah karangan dan pendapat sendiri. Plagiat dapat dianggap sebagai tindak pidana karena mencuri hak cipta orang lain. Di dunia pendidikan, pelaku plagiarisme dapat mendapat hukuman berat seperti dikeluarkan dari sekolah/universitas. 
3. Ali Hasan, Irma Kharisma Hatibie (2014) yang berjudul "PENGARUH ELEKTRONIKAL MARKETING TERHA-DAP MINAT WISATAWAN BERKUNJUNG KE PULAU SARONDE". E-Marketing adalah salah satu faktor yang memainkan peran penting dalam menjalankan bisnis pemasaran. E pemasaran atau pemasaran elektronik adalah salah satu terobosan yang cukup handal dalam memasarkan produk pariwisata. Penelitian ini menggunakan kuantitatif, data pengukuran dalam bentuk angka-angka. Variabel yang diteliti meliputi pemasaran facebook, email marketing, pemasaran web dan pemasaran blackberry messenger."

4. Penelitian ini telah dilakukan oleh Muhammad Zalnur (2012) yang berjudul "PLAGIARISME DI KALANGAN MAHASISWA DALAM MEMBUAT TUGASTUGAS PERKULIAHAN PADA FAKULTAS TARBIYAH IAIN IMAM BONJOL PADANG" Tujuan dari penelitian ini adalah untuk menggambarkan jenis plagiarisme yang dilakukan oleh siswa dalam menyelesaikan tugas-tugas pelajaran mereka. Ada tiga faktor yang membuat siswa melakukan plagiarisme, yaitu: (1) mengambil tulisan-tulisan lain dan mengakui mereka sebagai tulisan mereka sendiri, (2) mengambil ide-ide dari bagian dari tulisan orang lain dan mengubah ke bahasa sendiri, dan (3) mengambil semua bagian dari tulisan-tulisan tanpa mengubah ide-ide dan bahasa.

5. Penelitian ini telah dilakukan oleh Trianggo, Muh (2012) yang berjudul "Kebijakan Formulasi Sanksi Pidana Terhadap Tindak Pidana Penjiplakan (Plagiat) Karya Tulis Atau Skripsi” Penelitian ini bertujuan : (1)Untuk mengetahui kebijakan formulasi jenis perbuatan yang dikualifikasikan sebagai tindak pidana plagiarisme karya tulis atau skripsi; (2) Untuk mengetahui kebijakan formulasi sanksi pidana terhadap tindak pidana plagiarisme karya tulis atau skripsi.

6. Penelitian ini telah dilakukan oleh Meyliana, Henry Antonius E.W, Stehpen W. Santoso yang berjudul "Persepsi Pelanggan Terhadap Branding Pada Website Binus University" Penerapan e-Marketing atau digital marketing sangat membantu perusahaan dalam berkompetisi di era pasar bebas. Untuk itu, perusahaan perlu mendapatkan informasi tentang perpesi pelanggan dalam menilai e-marketing atau digital marketing yanf dimilikinya (website).

7. Penelitian ini telah dilakukan oleh Kartike Budi Lestari (2012) yang berjudul "Pengaruh Atribut Website dan Sumber Traffic Visitor Online Shop terhadap Keputusan Pembelian" Online shop sekarang ini muncul sebagai aplikasi populer dalam e-commerce, digunakan oleh beberapa jenis bisnis dengan tujuan yang berbeda. Melalui online shop pembelian dapat dilakukan tanpa terbatas oleh tempat.

8. Penelitian ini telah dilakukan oleh Susan Oktaviani yang berjudul "GO+ DALAM MENUNJANG INT+ UNTUK PENGELOLAAN DATA CMB PADA PERGURUAN TINGI" Masih banyak aspek lain dalam dunia internet marketing untuk diketahui oleh UKM. Tulisan ini akan membahas teknik biaya rendah dan alat-alat yang dapat dimanfaatkan dalam pemasaran produk dan jasa UKM. Salah satunya adalah memanfaatkan alat dari Google. teknik lain juga dibutuhkan untuk dapat mendominasi pasar internet.

9. Penelitian ini telah dilakukan oleh Kursehi Falgenti pada tahun 2011 dengan judul "TRANSFORMASI UKM KE BISNIS ONLINE DENGAN INTERNET 
MARnisiKETING TOOLS". Penelitian ini membahas tentang bagaimana cara mengantisipasi tindakan plagiat, dibutuhkan suatu cara yang dapat menganalisis teknikteknik plagiat yang dilakukan. Ada beberapa pendekatan yang bisa diambil, salah satunya dengan mempergunakan algoritma pencarian string Rabin-Karp.

10. Penelitian ini telah dilakukan oleh Herdy Febri Handoko pada tahun 2012 yang berjudul "PEMANFAATAN TEKNOLOGI INTERNET DALAM BISNIS". Internet dalam bisnis digunakan untuk pertukaran informasi, katalog produk, media promosi, surat elektronik, bulletin boards, kuesioner elektronik, dan mailing list. Internet juga bisa digunakan untuk berdialog, berdiskusi, dan konsultasi dengan konsumen secara on-line, sehingga konsumen dapat dilibatkan secara proaktif dan interaktif dalam perancangan, pengembangan, pemasaran, dan penjualan produk.

\section{PEMECAHAN MASALAH}

Dengan terjadinya permasalahan penyebaran informasi yang manual ini pada Perguruan Tinggi maka dari itu harus adanya suatu pemecahan masalah tersebut yaitu daftar dengan mulai menggunakan tool internet marketing dalam penyebaran informasi yang bernama MailChimp. tool internet marketing ini masih dalam tahap perkembangan. Dengan diterapkannya tool internet marketing ini dapat mengurangi penggunaan kertas dalam penyebaran informasi menjadi lebih efisien dan modern.

Berdasarkan penelitian dan analisa kekurangan dan kebutuhan perihal tool internet marketing di Perguruan Tinggi yang berjalan saat ini, tool internet marketing yang berjalan belum terlaksana dengan baik sehingga memberikan alternative pemecahan masalah dengan cara:

1. Dibutuhkan suatu tool internet marketing yang dapat menyebarkan informasi dengan menarik dan modern.

2. Tool internet marketing yang dapat digunakan oleh banyak orang.

3. Tool internet marketing dapat digunakan dimana saja dan kapan saja.

\section{IMPLEMENTASI}

1. Halaman Log In

Sebelum Log In pastikan sudah sign up dulu di MailChimp, terdapat icon unik yang menjadi ciri khas gambar monkey dengan senyum lebar dan memakai topi berwarna biru. 


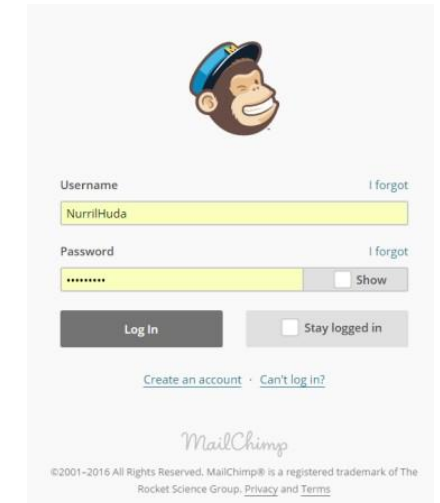

Gambar 2 Halaman Log In

2. Halaman desaign campaign adalah sebelumnya harus memilih template dahulu sesuai yang diinginkan dan kebutuhan di dalam halaman desaign ini banyak sekali button seperti content, desaign dan comments.

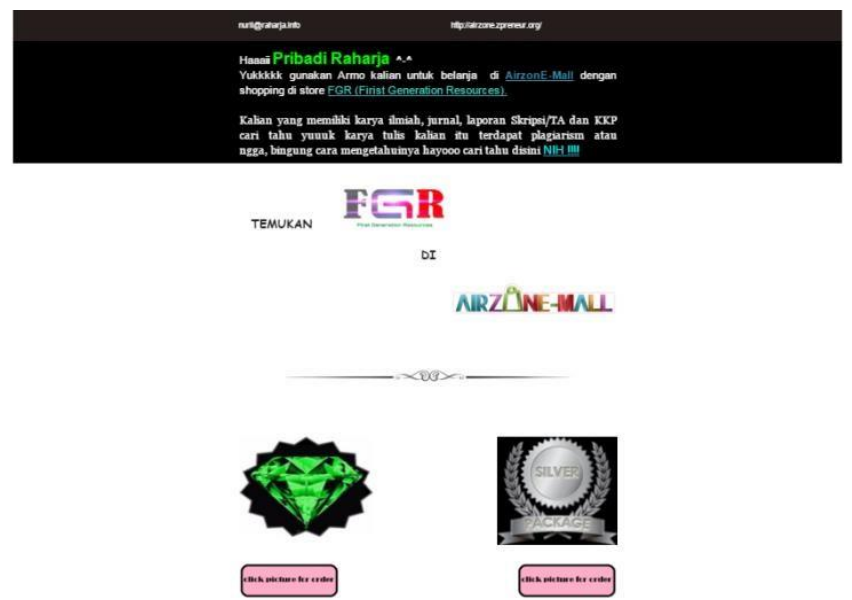

Gambar 3 Halaman Desaign FGR

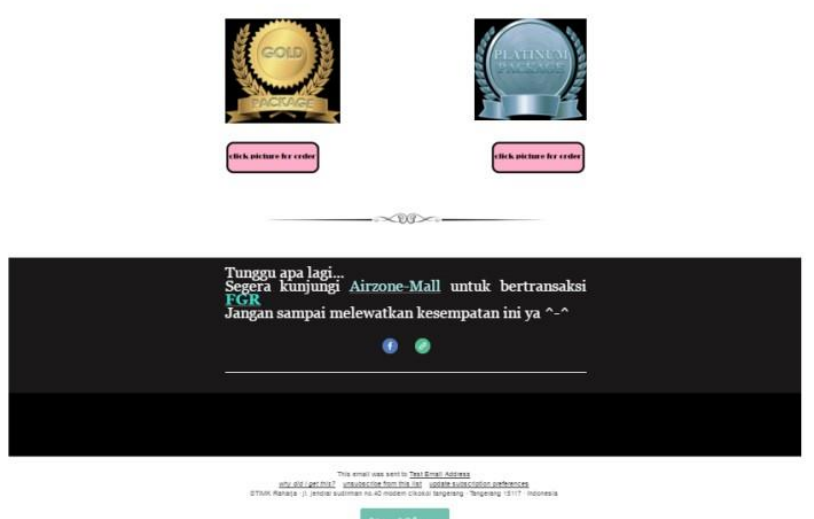

Gambar 3.1 Halaman Desaign FGR

3. Statistik performance adalah data email yang disebar kebanyak orang di dalam statistik perfomance terdapat jumlah perharinya dan perjam berapa yang telah membuka email campaign FGR tersebut. 


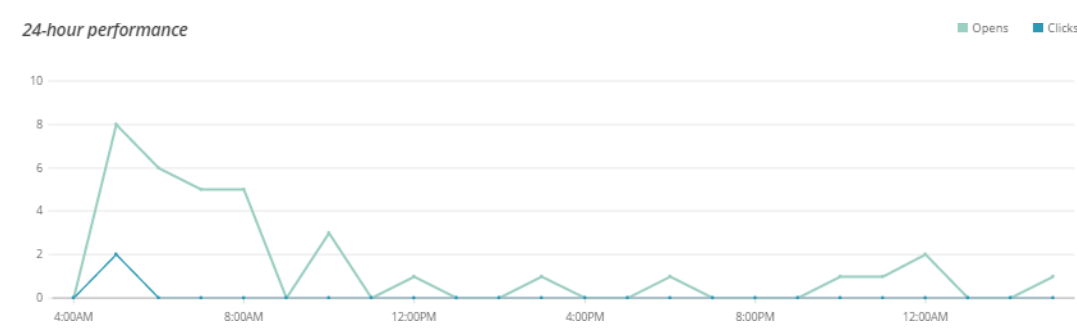

Gambar 4 Halaman Performance

4. Report opened adalah email yang sudah dikirim dari 150 email terdapat 67 email yang sudah buka campaign yang telah dikirim yang terdapat di dalam campaign, ini gambar list nama emailnya:

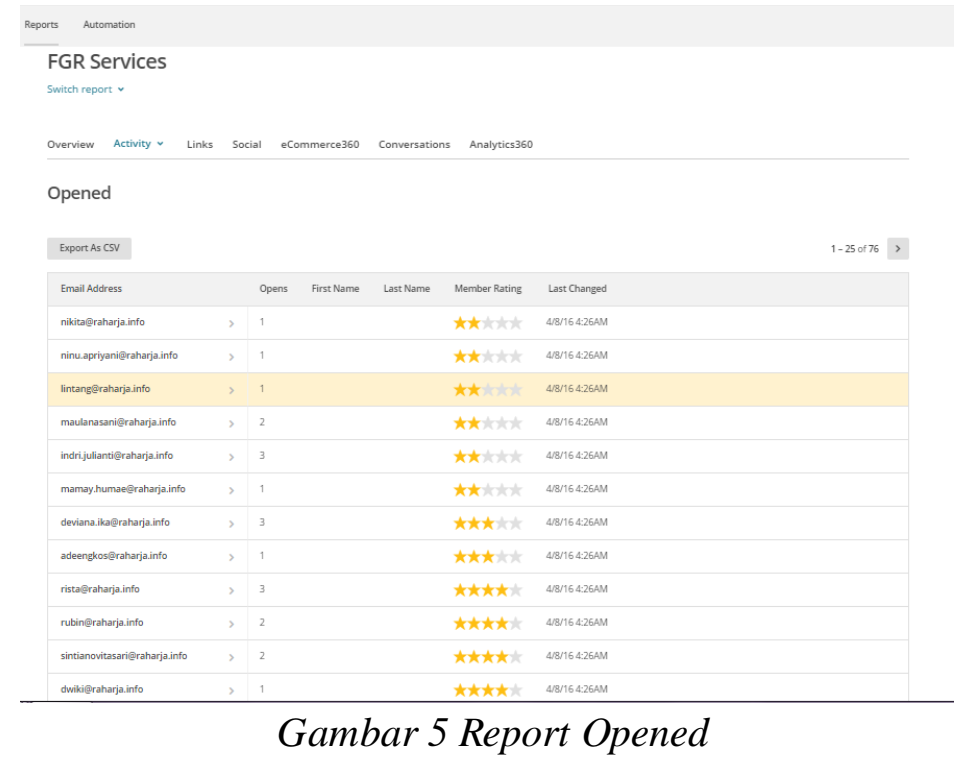

5. Report clicked adalah list email dari 150 email yang tersebar terdapat 15 clicked, itu tandanya bahwa orang yang sudah di kirimkan email campaign FGR telah membuka linklink yang terdapat di campaign.

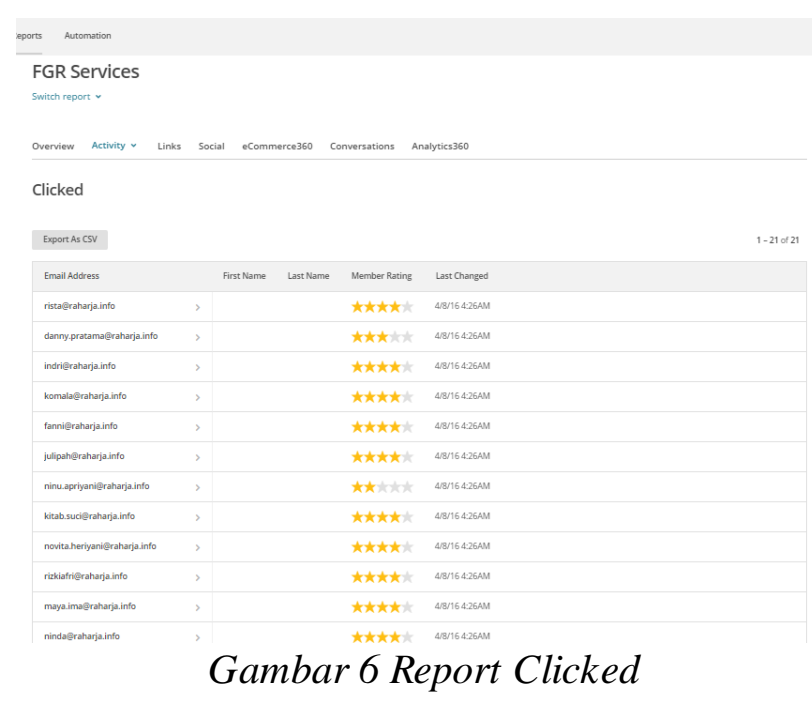

6. Click performance adalah link yang terdapat di dalam campaign dan yang sering dibuka terdapat total clicks dan unique cliks terlihat posisi teratas yaitu 
http://airzone.zpreneur.org/index.php/vendors/fgr_services-vendor-120 total click 53 $(27 \%)$.

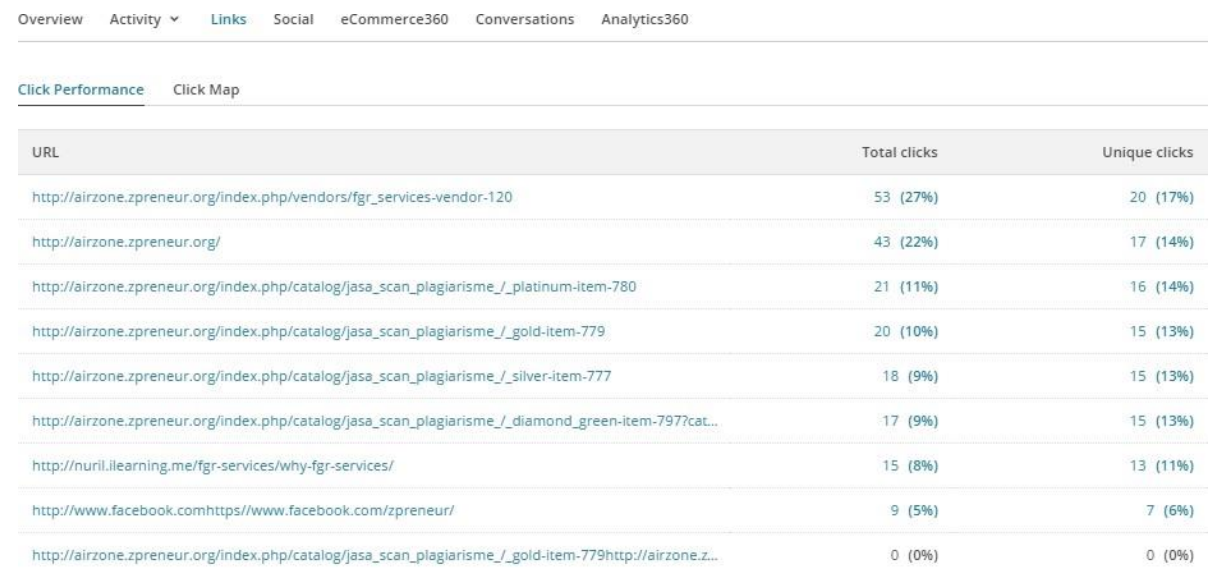

Gambar 7 Halaman Click Performance

7. Overview merupakan hasil report keseluruhan yaitu terdiri dari open rate terdapat $50,7 \%$, click rate tedapat $14,0 \%$, list average pada open rate terdapat $35,5 \%$ dan list average pada ckick rate terdapat $33,3 \%$.

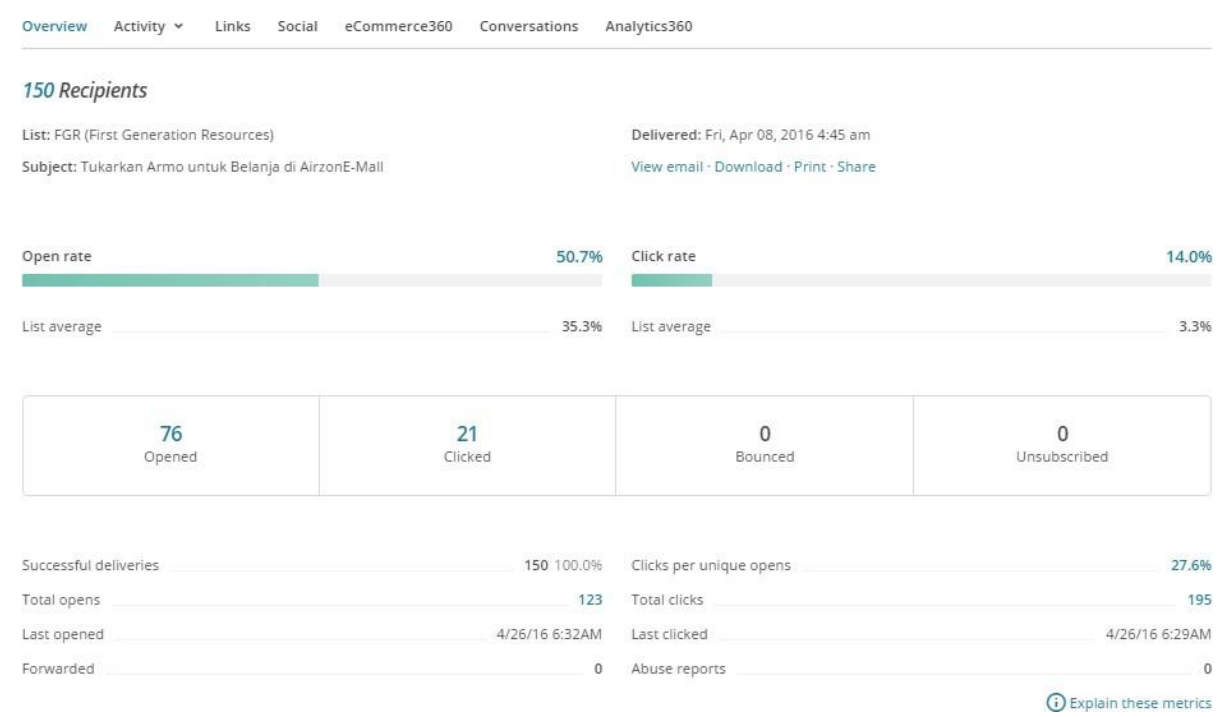

Gambar 8 Overview

\section{KELEBIHAN}

Terdapat 5 kelebihan dari MailChimp yaitu:

1. dapat menyebarkan informasi melaui email sampai ribuan email

2. template campaign yang banyak dan menarik

3. terdapat statistic performance

4. top links cliked

5. terdapat hasil report diantara: opened, clicked, bounced, unsubscribed

\section{KEKURANGAN}

1. Pada mailchimp saat kirim campaign masih kurang simple

2. Pada MailChimp template yang ada tidak semua bisa di edit sesuai kemauan 
3. pada saat memasukkan email kedalam list tidak secara otomatis pemberitahuan jika email terebut sudah tidak aktif

\section{KESIMPULAN}

Tool digital marketing seperti MailChimp ini dapat membantu dalam menyebarkan informasi FGR (First Generation Resources) jasa scan plagiarisme ke khalayak banyak karna media elektronik itu memang sangat mudah dalam hal penyebaran informasi bukan hanya mudah tetapi tampilan yang modern dan menarik. Diharapkan di Perguruan Tinggi menerapkan tool digital maerketing ini dalam penyebaran informasi ataupun promosi karna sangat bermanfaat.

\section{DAFTAR PUSTAKA}

[1] Yasa, I Wayan Putra (2010) yang berjudul Kejahatan Di dunia Maya (Cyber Crime).

[2] Wikipedia, "Plagiarisme". https://id.wikipedia.org/wiki/Plagiarisme] (Tanggal akses 25 April 2016)

[3] Karsidi, Ravik. 2015. Diakses pada tanggal 8 Desember 2015. Tersedia di http//uns. ac.id/id/uns-update/antisipasi-plagiarisme-uns-terapkan-similarity-test.html.

[4] Zalnur,Muhammad. PLAGIARISME DI KALANGAN MAHASISWA DALAM MEMBUAT TUGAS-TUGAS PERKULIAHAN PADA FAKULTAS TARBIYAH IAIN IMAM BONJOL PADANG.Padang: Fakultas Tarbiyah IAIN Imam Bonjol Padang. Jilid 1, Nomor 1 ,Februari 2012.

[5] Trianggo, Muh (2012) yang berjudul Kebijakan Formulasi Sanksi Pidana Terhadap Tindak Pidana Penjiplakan (Plagiat) Karya Tulis Atau Skripsi”

[6] Meyliana, Henry Antonius E.W, Stehpen W. Santoso. yang berjudul "Persepsi Pelanggan Terhadap Branding Pada Website Binus University". Jakarta: Binus University. Vol 3, Nomor 2 ,Desember 2012.

[7] Lestari, Kartike Budi (2012) yang berjudul "Pengaruh Atribut Website dan Sumber Traffic Visitor Online Shop terhadap Keputusan Pembelian".

[8] Oktaviani, Susan yang berjudul "GO+ DALAM MENUNJANG INT+ UNTUK PENGELOLAAN DATA CMB PADA PERGURUAN TINGI"

[9] Falgenti, Kursehi yang berjudul "TRANSFORMASI UKM KE BISNIS ONLINE DENGAN INTERNET MARKETING TOOLS”. Jakarta: Universitas Indraprasta PGRI. Vol. 4 No. 1 Maret 2011.

[10] Ali Hasan, Irma Kharisma Hatibie (2014) yang berjudul 'PENGARUH ELEKTRONIKAL MARKETING TERHA-DAP MINAT WISATAWAN BERKUNJUNG KE PULAU SARONDE". Yogyakarta: AMPTA. Vol. 1, Nomor 2, November 2014.

[11] Handoko, Febri Herdy (2012) yang berjudul "Pemanfaatan Teknologi Internet dalam Bisnis". Yogyakarta: STMIK AMIKOM.

[12] iMe. FGR (First Generation Resources). Diakses pada tanggal 8 Desember 2015. Tersedia di http://air.ilearning.me/2015/06/27/why-is-fgr/

[13] Widuri. MailChimp. Diakses pada tanggal 8 Desember 2015. Tersedia di http $/ /$ widuri.raharja.info/index.php?title=SI1112469591. 